\title{
Behaviour, tympanic temperature and performance of dairy cows during summer season in southern Chile
}

\author{
Respuesta fisiológica, de comportamiento y producción de vacas lecheras durante \\ el periodo estival en el sur de Chile
}

\author{
IE Jara ${ }^{a}$, JP Keim ${ }^{b}$, RA Arias ${ }^{\text {b* }}$ \\ aEscuela de Agronomía, Universidad Católica de Temuco, Temuco, Chile. \\ bInstituto de Producción Animal, Universidad Austral de Chile, Valdivia, Chile.
}

\begin{abstract}
RESUMEN
El objetivo del estudio fue evaluar los efectos de las condiciones climáticas del verano sobre la producción de leche, actividad animal y temperatura timpánica ( $(T T ; n=15)$, utilizando variables climáticas y tres índices de comodidad térmica. Los datos se analizaron considerando hora del día y categorías del índice comprensivo del clima (CCI). Se estimaron modelos de regresión simple para predecir la tasa de respiración $(\mathrm{RR})$ de las vacas $(\alpha=0,05)$. Los índices termales fueron normales y pobres predictores de $\mathrm{RR}\left(\mathrm{r}^{2}<0,35 ; \mathrm{P}<0,001\right)$. La proporción de animales en pastoreo, echados y rumiando se redujo ( $\mathrm{P}<0,002$ ) en 9,$4 ; 1,7 \%$; y 5,4 cuando el valor de $\mathrm{CCI} \geq 25$, mientras que los animales en pie y bajo sombra aumentaron 7,4 y 6,3\%. Además se registró una correlación positiva entre RR y CCI. Las vacas tuvieron mayores TT en las categorías de CCI "moderado" y "suave" vs. "normal", así como también para PM vs. AM. El mayor valor de TT se observó en los días con máximos valores en los índices térmicos. Hubo diferencias tanto en la producción de leche como en los valores de CCI entre AM vs. PM $(\mathrm{P}<0,001)$. Sin embargo, no hubo diferencias en la producción de leche entre las categorías de CCI $(\mathrm{P}=0,19)$. Aunque las vacas mostraron signos de estrés por calor la producción diaria de leche no disminuyó al asociarlas a las categorías de CCI, demostrando que los animales fueron capaces de enfrentar las condiciones climáticas estivales.
\end{abstract}

Palabras clave: comodidad térmica, cambio climático, bienestar animal.

\section{SUMMARY}

The objective of the study was to assess the effects of summer weather conditions on animal performance and behaviour in southern Chile. Data of milk yield, animal activity, tympanic temperatures (TT; $\mathrm{n}=15$ ), and three comfort thermal indices were collected in La Araucanía Disctrict. Time of day and comprehensive climate index (CCI) categories were considering as influential factors. Simple regression models were estimated to predict the respiration rate of cows as an estimator of thermal comfort. Daily values of thermal indices were poor predictors of respiration rate, as well as climatic variables $\left(\mathrm{r}^{2}<0.35 ; \mathrm{P}<0.001\right)$. During days with $\mathrm{CCI} \geq 25$ there was a reduction $(\mathrm{P}<0.002)$ in the proportion of animals on grazing $(9.4 \%)$, lying $(1.7 \%)$, and ruminating (5.4\%). The proportion of animals standing and under shade increased 7.4 and $6.3 \%$, respectively. Respiration rates were positively correlated with greater CCI values. The TT was higher for CCI categories "moderate" and "mild" vs. "normal" also for PM vs. AM. The highest TT was observed on days that had higher values of the thermal indices, especially CCI. There were differences for milk production and CCI values between AM vs. PM ( $\mathrm{P}<0.001)$. However, no differences for milk production were observed between CCI categories observed $(\mathrm{P}=0.19)$. In conclusion, although cows showed signs of heat stress daily milk production did not show differences among CCI categories, showing that they were able to cope adverse climatic conditions of summer in southern Chile.

Key words: thermal comfort, climate change, animal welfare.

\section{INTRODUCTION}

The majority of the most important cattle breeds used worldwide were developed in temperate zones and have been selected to maximize production under these environments, which has possibly resulted in more heat stress sensitive animals. While cattle adapts to various locations, in many localities mitigation mechanisms such as fans, sprinklers and artificial shade are commonly used to relieve heat stress (Hansen and Arechiga 1999). Likewise,

Accepted: 16.09.2015.

* rodrigo.arias@uach.cl there is also a growing concern in the global community for animal welfare and comfort. Physiological processes governing animal survival and production rely on its body temperature, which in turns depends on the surrounding environment (Mader 2003). When air temperature (AT) is higher than the comfort range, then heat loss will be reduced, moreover when AT is increased above the skin temperature, heat will then flow in the opposite direction (Córdova-Izquierdo 2010). Therefore, changes on climatic environment implies that an animal have to spend energy to regulate their body temperature within a range that varies from $37.5{ }^{\circ} \mathrm{C}$ to $39.0{ }^{\circ} \mathrm{C}$ (Dos Santos 1999) instead of diverting it to productive functions. Thus, total heat load that an animal receives are due in part to increased caloric 
product of energy metabolism and secondly due to the net energy exchange with its surrounding environment (Finch 1986). From a bioclimatic standpoint, animal responses to the warm atmosphere are related in various ways; and evidently involve the direct effects of body temperature by altering the regulation of the nervous system, fluid balance, hormone levels, nutritional balance and biochemical balance (Uribe-Velásquez et al 2001). However, under natural conditions in which cattle grow and produce, the situation might be more complex. Besides ambient AT other climate factors such as solar radiation, humidity, and wind speed can increase or decrease the thermal load received.

In Chile there is a lack of information regarding the effects of weather conditions on cattle physiology, behaviour and performance (Arias et al 2008). However, climate records indicate a potential heat stress for grazing dairy cattle in some regions (Arias and Mader 2010). Therefore, the objective of this study was to evaluate the effects of summer climatic conditions on heat stress, behaviour and performance of dairy cows in southern Chile.

\section{MATERIAL AND METHODS}

The study was conducted from January 18 to 22 of 2013 at Pillanlelbún, $15 \mathrm{~km}$ northeast from Temuco city. A total of 15 multiparous dairy cows (Friesian x Holstein) were randomly selected from the herd. Cows were blocked by period of lactation divided into three groups of five cows each ( 7 to 8 months of lactation; 5 to 6 months of lactation; and 2 to 4 months of lactation). Cows were offered summer turnips (Brassica rapa) during the morning and a ryegrass-white clover pasture during the afternoon. In addition a commercial concentrated was supplied at the parlour during milking (16 std, Champion).

\section{DATA COLLECTION ANIMAL BEHAVIOUR, AND WEATHER}

Tympanic temperatures: The tympanic temperature (TT) was used as indicator of body temperature and thermal comfort. Data logger devices (ibuttons, Maxim Integrated Products Inc., CA) were manually installed in the tympanic canal following the same procedure declared by Arias et al (2011).

Animal behaviour: Individual animal behaviour was recorded by observation, three times per day (10:00, 15:00 $\mathrm{h}$ and 18:00 h). Animal activity was classified as grazing, drinking, ruminating, standing, lying or under shade. Additionally, animals were observed and assigned a panting score based on described by Mader y col (2002). Finally, respiration rates $(\mathrm{RR}$; breaths per minute $=\mathrm{bpm})$ were estimated by counting animal's flank movement.

Milk yield: Individual milk yield (kg/d) for morning (06:00 h) and evening (17:00 h) were recorded by using a proportional-milk meter (DeLaval).

Weather data: Climatic data were obtained from a meteorological weather station located at the farm
(A720, ADCON Telemetry GMBH, Austria), including: wind speed (WS; km/h), ambient temperature (AT, ${ }^{\circ} \mathrm{C}$ ), relative humidity $(\mathrm{RH} ; \%)$, precipitations $(\mathrm{PP}, \mathrm{mm} / \mathrm{d})$, and net solar radiation $\left(\mathrm{SR} ; \mathrm{W} / \mathrm{m}^{2}\right)$. The values of TT and climatic variables were averaged at one-hour intervals for further analysis.

Thermal indices: Animal thermal comfort was evaluated by using three thermal indices, which were estimated by the equations developed by Hahn et al (2009), Mader et al (2006), and Mader et al $\left(2010^{\mathrm{b}}\right)$, for THI, THI adjusted (by wind speed and solar radiation), and the Comprehensive Climate index, respectively.

\section{STATISTICAL ANALYSIS}

All data were analysed with the statistical package JMP 11 (SAS Institute Inc. NC., USA) under a complete block randomize experimental design, considering time of day (morning, afternoon and evening) and CCI categories (Mader y col $2010^{\mathrm{b}}$ ) as influential factors. Categorical variables were analysed by using Chi-square tests, while TT, RR, and milk yield were analysed by ANOVA. Subsequently, simple regression models were estimated to predict the RR using climatic factors and thermal comfort indices as predictors. All statistical analyses considered $\alpha=0.05$.

\section{RESULTS AND DISCUSSION}

Table 1 summarises weather variables collected as well as TT and the thermal comfort indices. Neither the THI nor the $\mathrm{THI}_{\mathrm{adj}}$ value was above the threshold needed to reach heat stress, but there were differences among days $(\mathrm{P}<0.05)$. The THI is the most known and used thermal index in livestock and their thresholds have remained unmodified. However, THI threshold was reduced recently from 72 to 68 (Zimbelman et al 2009) due to change on animal genetic and sensibility. There were three days showing values over the threshold for THI and two days with $\mathrm{THI}_{\mathrm{adj}}$ and CCI (19 and 20 of February). Likewise, the highest TT were recorded on those same days. Those days, there was a combination of the highest AT records of all the summer period in the region, reaching a maximum of $36.2{ }^{\circ} \mathrm{C}$ on January $19^{\text {th }}$, plus high solar radiation, increasing the heat load on cows.

\section{RELATIONS BETWEEN TYMPANIC TEMPERATURE, CLIMATIC VARIABLES AND THERMAL COMFORT INDICES}

The patterns of curves for TT, AT and CCI were similar (figure 1A) increasing throughout the day, except for TT during the period from 17:00 to 18:00 h, probably because cows were into the milking parlour and not being exposed to direct SR. The SR had minimum values at night, but quickly increase after 07:00 $\mathrm{h}$ along with sunrise, and reaching a maximum value of $831.90 \mathrm{~W} / \mathrm{m}^{2}$ at $15: 00$ h. During this period (08:00 to 16:00 h), TT increased 
Table 1. Daily mean values for climatic variables, thermal comfort indices and tympanic temperature of cows during the study period. Valores diarios promedios de las variables climáticas, índices de comodidad termal y de temperatura timpánica de las vacas durante el periodo de estudio.

\begin{tabular}{|c|c|c|c|c|c|c|c|c|}
\hline Date & $\mathrm{TT}^{*}$ & WS & AT & RH & SS & THI $^{*}$ & $\mathrm{THI}_{\mathrm{adj}}{ }^{*}$ & $\mathrm{CCI}^{*}$ \\
\hline $16 / 01 / 13$ & $37.8^{\mathrm{b}}$ & 6.8 & 21.3 & 85.2 & 513.4 & $68.9^{\mathrm{a}}$ & $63.3^{\mathrm{de}}$ & $21.6^{\mathrm{c}}$ \\
\hline $17 / 01 / 13$ & $37.5^{\mathrm{cd}}$ & 3.4 & 17.4 & 90.5 & 260.5 & $62.4^{\mathrm{cd}}$ & $62.0^{\mathrm{e}}$ & $17.7^{\mathrm{d}}$ \\
\hline $18 / 01 / 13$ & $37.6^{\mathrm{c}}$ & 3.3 & 19.2 & 88.1 & 288.7 & $65.0^{\mathrm{cd}}$ & $65.0^{\mathrm{cd}}$ & $21.2^{\mathrm{c}}$ \\
\hline $19 / 01 / 13$ & $38.1^{\mathrm{a}}$ & 1.9 & 24.8 & 74.5 & 326.2 & $71.9^{\mathrm{a}}$ & $74.9^{\mathrm{a}}$ & $29.5^{\mathrm{a}}$ \\
\hline $20 / 01 / 13$ & $37.9^{\mathrm{ab}}$ & 2.3 & 23.2 & 79.2 & 284.6 & $70.3^{\mathrm{a}}$ & $72.1^{\mathrm{b}}$ & $27.5^{\mathrm{b}}$ \\
\hline 21/01/13 & $37.7^{\mathrm{c}}$ & 3.3 & 19.6 & 92.2 & 272.1 & $66.4^{\mathrm{bc}}$ & $66.1^{\mathrm{c}}$ & $22.1^{\mathrm{c}}$ \\
\hline $22 / 01 / 13$ & $37.6^{\mathrm{c}}$ & 3.3 & 19.4 & 95.2 & 215.2 & $66.4^{\mathrm{bc}}$ & $65.8^{\mathrm{cd}}$ & $21.5^{\mathrm{c}}$ \\
\hline Average & 37.7 & 3.5 & 20.7 & 86.4 & 308.7 & 67.3 & 67.0 & 23.0 \\
\hline SEM & 0.2 & 1.6 & 2.6 & 7.4 & 96.3 & 3.3 & 4.7 & 4.1 \\
\hline
\end{tabular}

$\mathrm{TT}=$ daily mean tympanic temperature $\left({ }^{\circ} \mathrm{C}\right) ; \mathrm{WS}=$ daily mean wind speed $(\mathrm{km} / \mathrm{h}) ; \mathrm{AT}=$ daily mean air ambient temperature $\left({ }^{\circ} \mathrm{C}\right) ; \mathrm{RH}=$ daily mean relative humidity (\%); $\mathrm{SR}=$ daily mean net solar radiation $\left(\mathrm{W} / \mathrm{m}^{2}\right)$; THI= daily mean temperature-humidity index (adimensional); $\mathrm{THI}_{\text {adj }}=$ daily mean adjusted temperature-humidity index (adimensional); $\mathrm{CCI}=$ Comprehensive climate index $\left({ }^{\circ} \mathrm{C}\right)$; y SEM= standard error of the mean.

*Different superscripts indicate statistical differences within columns (Tukey test, $\mathrm{P}<0.0001$ ). No statistical analysis was performed for WS, AT, RH and SS.

along with SR, until mean TT value presented a slight decrease at the time of the afternoon milking (16:00 to 18:00 $\mathrm{h}$ ), but rising again and reaching similar values than those recorded previously to the afternoon milking. After 20:00 h, TT began to decrease with a delay of 4 hours after maximum SR was reached. The WS increased from near zero to a maximum value of $9.27 \mathrm{~km} / \mathrm{h}$ at $20: 00 \mathrm{~h}$, coinciding with the time of day at which TT begins to decrease. However, both values dropped sharply after this time. The THI and $\mathrm{THI}_{\text {adj }}$ presented a very similar patterns with values increasing as the day progressed, but with major differences after 17:00 $\mathrm{h}$, where $\mathrm{THI}_{\text {adj }}$ began to decrease quickly (figure 1B). However, at 23:00 $\mathrm{h}$ both indices reached the same value.

The TT increased from 8:00 $\mathrm{h}$ reaching a maximum of $38.18{ }^{\circ} \mathrm{C}$ at $15: 00 \mathrm{~h}$, and began to decrease at 19:00 h. The TT was higher $(\mathrm{P} \leq 0.05)$ for the "extreme" and "severe" CCI categories ( 38.53 and $38.48{ }^{\circ} \mathrm{C}$, respectively) followed by the categories "moderate" and "mild" (38.08 and $37.93{ }^{\circ} \mathrm{C}$, respectively), with "no stress" showing the lowest TT value $\left(37.51^{\circ} \mathrm{C}\right)$.

\section{ANIMAL ACTIVITY, RESPIRATION RATES AND PANTING SCORES}

When cows were on the CCI category of "no stress" there was a predominance of grazing activities $(58.3 \%)$, while $20.6 \%$ were lying, and $9.3 \%$ were standing. The remaining $11.8 \%$ were ruminating under natural shade and drinking. Meanwhile, on days with a "mild" CCI category, there was a lower percentage of animals grazing compared to the "no stress" CCI category, but it still remains as the main activity observed $(48.9 \%)$. The percentage of lying animals was similar (18.9\%), but increased the percentages of animals standing (16.7\%), drinking (3.3\%), and under shade (8.9\%); while decreased the ruminating activity (3.3\%). This reflects a change on animal behaviour as a function of environmental conditions. Other studies have reported that creating a microclimate by shade of trees has a positive effect on animal performance, due to changes in the behaviour and productivity of grazing animals (Blackshaw and Blackshaw 1994). These changes increased the time spent by animals grazing and ruminating, decreased water requirements, increased voluntary DMI, decreased mortality of young animals, and improved herd reproductive performance; therefore improving cattle performance (Johnson et al 1962, Djimde et al 1989). According to Stockdale and King (1983), cows spend, on average, $40 \%$ of their time grazing and $27 \%$ ruminating. Meanwhile, Phillips (1993) reported slightly lower values (38\% of the day grazing, 23\% lying and ruminating, and 10\% standing and ruminating) which agrees with the values given by Hodgson (1990) with $35.8 \%$ of time grazing and $32.5 \%$ ruminating. Fraser and Broom (1990) showed that, in summer, lactating cows had more leisure time that corresponds to the period at which an animal is not eating, chewing or drinking, and generally it corresponds to 5:48 to $12: 48 \mathrm{~h}$ per day. This means that animals replace activities related to feeding behaviour (eating and rumination) for leisure, in an attempt to reduce metabolic heat production. In the present study, on average, $56.9 \%$ of the animals were grazing; $19.4 \%$ lying; $11.7 \%$ standing; $6.7 \%$ ruminating; $4.3 \%$ under the shade; and only $1 \%$ drinking. However, it is worth mentioning that these values represent a snapshot (of three moments of day) of the proportion of cattle in those activities and not the proportion of time expended on that.

During the first 4 days of observation average values of RR exceeded 60 bpm (threshold value), reaching an average 
A

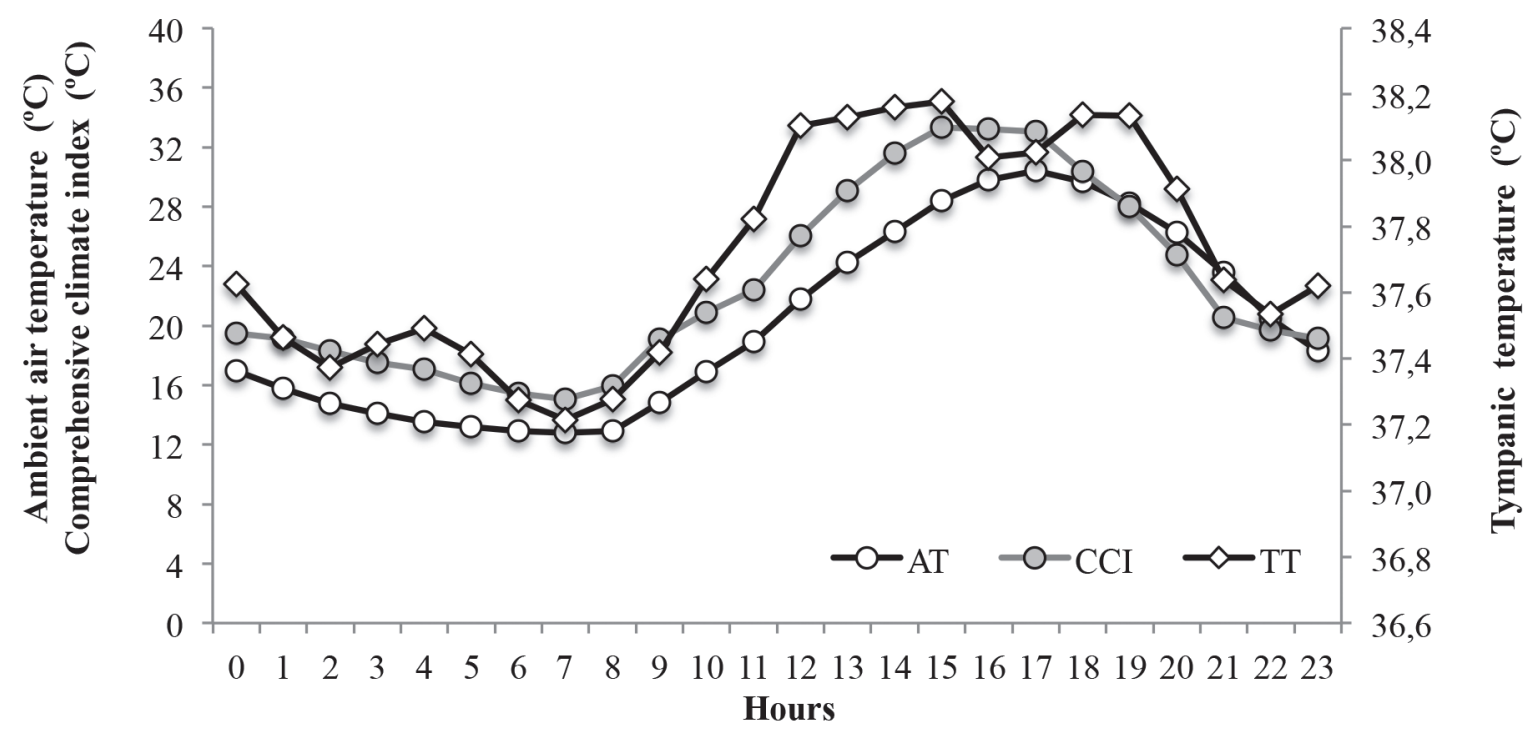

B

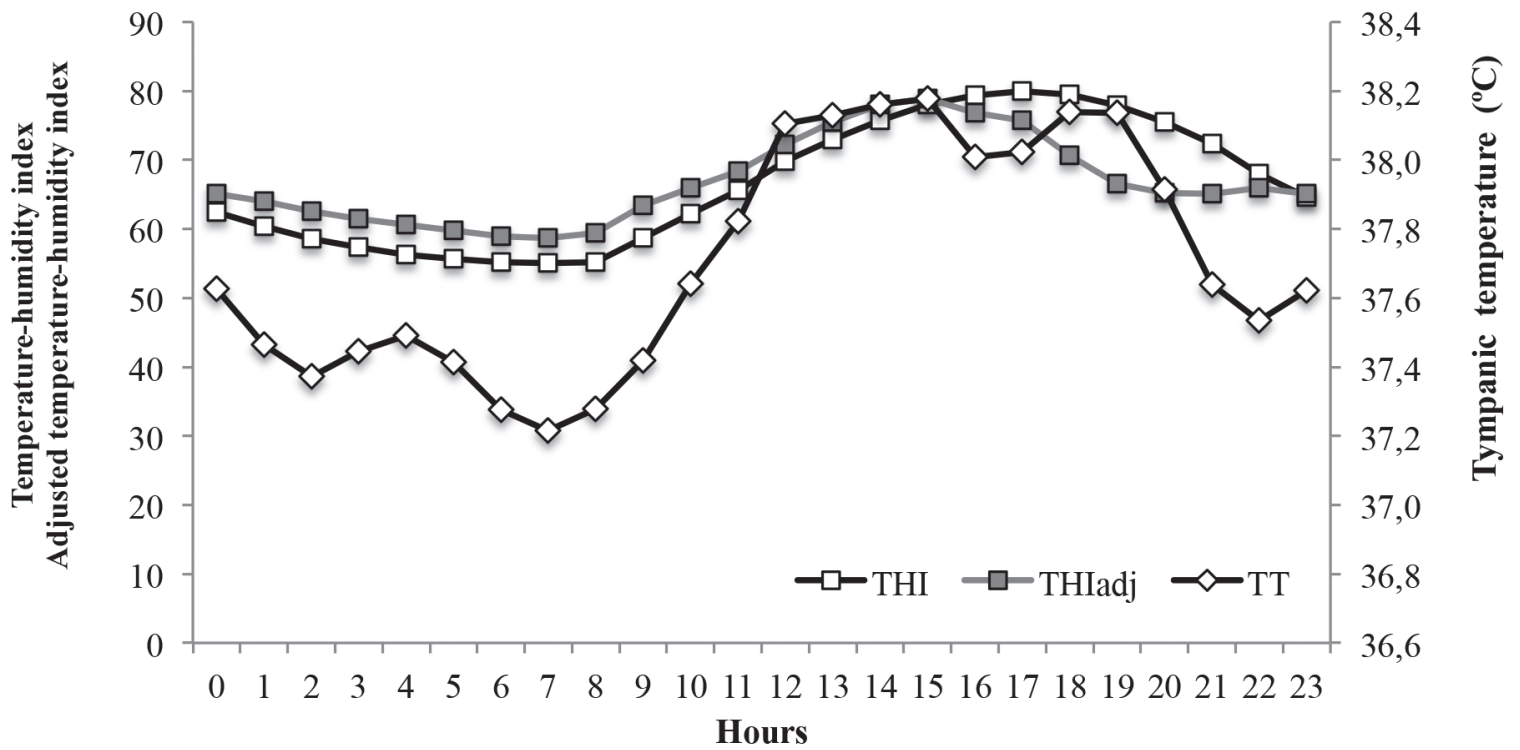

Figure 1. Relationships of tympanic temperatures (TT) of cows and thermal comfort indices. A) Relationship of TT and Comprehensive climatic index (CCI) plus ambient temperature (AT). B) Relationship of TT and temperature-humidity index (THI) plus adjusted THI $\left(\mathrm{THI}_{\text {adj }}\right)$.

Relaciones de la temperatura timpánica (TT) de las vacas con índices de comodidad termal. A) Relación de la TT con el índice comprensivo del clima (CCI) y la temperatua ambiente (AT). B) Relación de la TT con el índice de temperatura-humedad (THI) y THI ajustado (THI adj).

maximum of around 80 bpm on January 19 and 20, but with some cows showing values $>100 \mathrm{bpm}$. Again those two days presented the highest values of THI (71.9), THI $_{\text {adj }}$ (74.9) and CCI $\left(29.5^{\circ} \mathrm{C}\right)$, which could be considered as a small heat wave. An increased RR represents a strategy of cattle to dissipate heat, even when it is not an effective pathway under very extreme heat stress conditions, since lung area of cows is very small regarding to the volume body mass (Oberto et al 2006). According to Schneider et al (1998), animals under heat stress increases RR and reduces $\mathrm{CO}_{2}$ content in the blood, resulting in a respiratory alkalosis. In this study a higher RR was observed when CCI was higher, showing that cow had to dissipate the heat load received during the day, especially during the afternoon. Brown-Brandl et al (2005) found that RR is the most effective indicator to monitoring heat stress in cattle. In addition, on January $19^{\text {th }}$ a $25 \%$ of cows had panting scores (PS) of 2 and 65\% PS of 1, which results 
in $90 \%$ with PS $>0$. The following day that proportion fell to $76 \%$ agreeing with the lower values of $\mathrm{THI}_{\text {adj }}$ and $\mathrm{CCI}$ values observed. The PS is a visual tool related to RR developed to assess heat stress in animals ranging from 0 $=$ normal respiration to $4=$ heavy open-mouthed panting (Mader et al 2002, Mader et al 2006). Díaz-Royón and García (2013) indicate that during panting, cows drool and lose saliva, which is an additional loss of fluid and ruminal buffering and also implies a greater need of water for cows. According to Mader et al (2006) a measurement of PS taken 2 hours before the prevalence of warmer climatic conditions regarding the observable effects on cattle would indicate the time that takes the body of the animal (and metabolism) to gain heat from the environment. The utilization of PS and RR would allow implementing mitigation mechanisms effectively.

In the present study there were differences between the AM vs. PM milk yield $(\mathrm{P}<0.001)$. However, no differences in milk yield were observed among CCI categories $(P=0.19)$. When body temperature increases causes an increased up to one degree Celsius in rectal and tympanic temperature, increased respiratory rate (panting), causing severe reductions in voluntary feed intake (Lough et al 1990), a decline on growth rates and also milk production (Elvinger et al 1992), as well as impaired reproductive function and secretion of thyroid hormones (Al-Haidary et al 2001).

Mader et al (2010) concluded that cattle with moderate levels of heat stress were able to cool down at night keeping a moderate TT the next day. In this study AT dropped sharply from values above $30^{\circ} \mathrm{C}$ to near to $10^{\circ} \mathrm{C}$.

Even although we did not find differences in milk production, the literature reports that a combination of high SR plus high air temperatures have negative effects on milk production composition (Roman-Ponce et al 1997). Maust et al (1972) reported that for all stages of lactation, $9 \%$ of the variation in milk yield, $13 \%$ in milk fat, $5 \%$ in feed intake and $65 \%$ in rectal temperature were attributable to weather conditions. The critical temperature at which milk production begin to decrease fluctuates between 21.0 and $26.5{ }^{\circ} \mathrm{C}$ for Holstein and Jersey cows, respectively (Kadzere et al 2002). In this study there was over a third of days with AT $>21$, but no changes in milk production. This reveals that AT by itself it is not the best predictor. Likewise, an increasing on AT may also cause changes in the distribution of water in the animal, promoting a reduction in the water content in milk obtained during milking in the afternoon. This effect is exacerbated in animals without access to shade. In this regard, Beede et al (1993) mention that the night cooling can restore milk production, but its effect in the foreground is to restore the DMI. In addition, animals with high potential of production are more susceptible to the effects of heat stress. In this study, cows had a moderate potential of milk production and also had cool nights that allowed them to lose the heat accumulated during daytime.
Summer weather conditions challenged the behaviour and physiology of dairy cows, which increased their respiration rates, panting, and the use of shadow. Likewise they reduced the time spend on grazing when $\mathrm{CCI}$ values were higher than normal. Finally, cool nights and the moderate productive potential of cows might have helped them to cope with the heat load.

\section{ACKNOWLEDGEMENTS}

This work was possible due to the support of the Chilean National Fund for Science and Technology (FONDECYT, Project 11121320; Santiago, Chile)

\section{REFERENCES}

Al-Haidary A, DE Spiers, GE Rottinghaus, GB Garner, MR Ellersieck. 2001. Thermoregulatory ability of beef heifers following intake of endophyte-infected tall fescue during controlled heat challenge. $J$ Anim Sci 79, 1780-1788.

Arias RA, TL Mader, PC Escobar. 2008. Climatic factors affecting cattle performance in dairy and beef farms. Arch Med Vet 40, 7-22.

Arias RA, TL Mader. 2010. Determination of potential risk of heat stress of cattle in four locations of Central and Southern Chile. Arch Med Vet 42, 33-39.

Arias RA, TL Mader, AM Parkhurst. 2011. Effects of diet type and metabolizable energy intake on tympanic temperature of steers fed during summer and winter seasons. J Anim Sci 89, 1574-1580.

Beede D, R Bray, F Bucklin. 1993. Planifique su estrategia contra el calor. Venezuela Bovina 7, 38-39.

Blackshaw JK, AW Blackshaw. 1994. Heat stress in cattle and the effect of shade on production and behaviour: a review. Aust J Exp Agr 34, 285-295.

Brown-Brandl TM, RA Eigenberg, JA Nienaber, GL Hahn. 2005. Dynamic response indicators of heat stress in shaded and non-shaded feedlot cattle, part 1: Analyses of indicators. Biosyst Eng 90, 451-462.

Córdova-Izquierdo A. 2010. The binomial stress- adaptation and animal welfare as axes in veterinary education. Revista Electrónica de Veterinaria 11, 1695-7504.

Díaz-Royón F, A García. 2013. ¿Dietas de verano con más o menos forraje en vacuno lechero? Veterinaria Albéitar 42, 189.

Djimde M, F Torres, W Migongo-Bake. 1989, Climate animal and agroforestry. International workshop on the application of meteorology to agroforestry systems planning and management. International Council for Research in Agroforestry (ICRAF), Nairobi, Kenia, Pp 463-470.

Dos Santos R. 1999. Os cruzamentos na pecuária tropical. Ed. Agropecuaria Tropical, Uberaba, Brasil.

Elvinger F, RP Natzke, PJ Hansen. 1992. Interactions of heat stress and bovine somatotropin affecting physiology and immunology of lactating cows. J Anim Sci 75, 449-462.

Finch VA. 1986. Body temperature in beef cattle: Its control and relevance to production in the tropics. J Anim Sci 62, 531-542.

Fraser AF, DM Broom. 1990. Farm animal behaviour and welfare. $3^{\text {rd }}$ ed. Bailliére and Tindall, London, UK.

Hansen PJ, CF Arechiga. 1999. Strategies for managing reproduction in the heat-stressed dairy cow. J Anim Sci 77, 36-50.

Hodgson J. 1990. Grazing management: science into practice. Longman Handbooks in Agriculture, Essex, England.

Johnson HD, AC Ragsdale, IL Berry, MD Shanklin. 1962. Effect of various temperature-humidity combinations on milk production of Holstein cattle. Agricultural Experimental Station Research Bulletin No. 791. University of Missouri, Columbia, USA.

Kadzere CT, MR Murphy, N Silanikove, E Maltz. 2002. Heat stress in lactating dairy cows: a review. Livest Prod Sci 77, 59-91. 
Lough DS, DK Beede, CJ Wilcox. 1990. Effects of feed intake and thermal stress on mammary blood flow and other physiological measurements in lactating dairy cows. J Anim Sci 73, 325-332.

Mader TL, SM Holt, GL Hahn, MS Davis, DE Spiers. 2002. Feeding strategies for managing heat load in feedlot cattle. J Anim Sci 80, 2373-2382.

Mader TL. 2003. Environmental stress in confined beef cattle. J Anim Sci 81, E110-119.

Mader TL, MS Davis, T Brown-Brandl. 2006. Environmental factors influencing heat stress in feedlot cattle. J Anim Sci 84, 712-719.

Mader TL, JB Gaughan, LJ Johnson, GL Hahn. 2010. Tympanic temperature in confined beef cattle exposed to excessive heat load. Int J Biometeorol 54, 629-635.

Maust LE, RE McDowell, NW Hooven. 1972. Effect of summer weather on performance of Holstein Cows in three stages of lactation. $J$ Dairy Sci 55, 1133-1139.

Oberto MF, MA Reitú, MA Pirra. 2006. Estrés calórico: ¿Qué podemos hacer? ¿Dietas frías, manejo del ambiente? Producir XXI 15, 36-39.

Phillips CJC. 1993. Cattle behaviour. Farming Press Books, Ipswich, England.
Roman-Ponce H, WW Thatcher, DE Buffington, CJ Wilcox, HH Van Horn. 1997. Physiological and production responses of dairy cattle to a shade structure in subtropical environment. J Dairy Sci 60, 424-430.

Schneider PL, DK Beede, CJ Wilcox. 1998. Nycterohemeral patterns of acid base status, mineral concentrations and digestive function of lactating cow in natural or chamber heat stress environments. $J$ Anim Sci 66, 112-125.

Stockdale C, K King. 1983. Effect of stocking rate on the grazing behaviour and faecal output of lactating dairy cows. Grass Forage Sci 38, 215-218.

Uribe-Velásquez LF, E Oba, LHdA Brasil, FNd Sousa, FS Wechsler. 2001. Efeitos do estresse térmico nas concentrações plasmáticas de progesterona (P4) e estradiol 17-b (E2) e temperatura retal em cabras da raça Pardo Alpina. Rev Bras Zootecn 30, 388-393.

Zimbelman RB, RP Rhoads, ML Rhoads, GC Duff, LH Baumgard, RJ Collier. 2009. A re-evaluation of the impact of temperature humidity index (THI) and black globe humidity index (BGHI) on milk production in high producing dairy cows. Proceedings of the $24^{\text {th }}$ Southwest Nutrition and Management Conference. Tempe, Arizona, USA, Pp 158-169. 